\title{
Investigation of the Effects of Silage Type, Silage Consumption, Birth Type and Birth Weight on Live Weight in KIvırcık Lambs With MARS and Bagging MARS Algorithms.
}

\section{Ömer ŞENGÜL}

Bursa Uludag University: Bursa Uludag Universitesi

Şenol Çelik ( $\square$ senolcelik@bingol.edu.tr)

Bingol University: Bingol Universitesi https://orcid.org/0000-0001-5894-8986

Ibrahim AK

Uludağ Universitesi: Bursa Uludag Universitesi

\section{Research Article}

Keywords: Kıvırcık lamb, silage, silage consumption, birth type, birth weight, data mining

Posted Date: November 10th, 2021

DOI: https://doi.org/10.21203/rs.3.rs-1027294/v1

License: (c) (1) This work is licensed under a Creative Commons Attribution 4.0 International License.

Read Full License 


\section{AUTHORS:}

2

3

4

5 Investigation of the effects of silage type, silage consumption, birth type and birth

6 weight on live weight in Kıvırcık lambs with MARS and Bagging MARS algorithms

AFFILIATIONS OF AUTHORS:

9 ${ }^{2}$ Bingöl University, Faculty of Agriculture, Dept. of Animal Science Bingöl-Turkey

CORRESPONDING E-MAIL:

senolcelik@bingol.edu.tr 
Investigation of the effects of silage type, silage consumption, birth type and birth weight on live weight in Kıvırcık lambs with MARS and Bagging MARS algorithms

\author{
Ömer ŞENGÜL ${ }^{1} \quad$ Şenol ÇELIK ${ }^{2} \quad$ İbrahim $\mathrm{AK}^{1}$ \\ ${ }^{1}$ Bursa Uludağ University, Faculty of Agriculture, Dept. of Animal Science Bursa-Turkey \\ ${ }^{2}$ Bingöl University, Faculty of Agriculture, Dept. of Animal Science Bingöl-Turkey
}

Abstract: This study was carried out to determine the effect of silage type, silage consumption, birth type (single or twin) and birth weight on live weight at the end of fattening in Kivircik lambs. In the experiment, 40 male Kivircik lambs aged 2.5-3 months were used and the animals were fattened for 56 days. During the fattening period, the lambs fed with 5 different types of silage $(100 \%$ sunflower silage, $75 \%$ sunflower $+25 \%$ corn silage, $50 \%$ sunflower $+50 \%$ corn silage, $25 \%$ sunflower $+75 \%$ corn silage, $100 \%$ corn silage) pure and mixed in different proportions and concentrate feed. Data on fattening results were analyzed with MARS and Bagging MARS algorithms. The main objective of this research is to predict live weight of lambs using Multivariate Adaptive Regression Splines (MARS) and Bagging MARS algorithms as a nonparametric regression technique. Live weight value was modeled based on factors such as birth type, birth weight, silage type and silage consumption. Correlation coefficient ( $r$ ), determination coefficient $\left(\mathrm{R}^{2}\right)$, Adjust $\mathrm{R}^{2}$, Root-mean-square error (RMSE), standard deviation ratio (SD ratio), mean absolute percentage error (MAPE), mean absolute deviation (MAD), and Akaike Information Criteria (AIC) values of MARS algorithm predicting live weight were as follows: 0.9986, 0.997, 0.977, 0.142, 0.052, 0.2389, 0.086 and -88 respectively. Like statistics for Bagging MARS algorithm were 0.754, 0.556, 0.453, 1.8, 0.666, 3.96, 1.47 and 115 respectively. It was observed that MARS and Bagging MARS algorithms have revealed correct results according to goodness of fit statistics. However, it has been revealed that MARS algorithm gives better results in live weight modeling.

Keywords: Kıvırcik lamb, silage, silage consumption, birth type, birth weight, data mining.

\title{
Introduction
}

Approximately $70 \%$ of the expenses of the enterprises engaged in animal production are roughage and intensive feed costs (Kara and Eroğlu, 2018). This is very important in terms of showing how effective and decisive the feed is in the development of livestock. Today, where the demand for animal products is increasing, more and more roughage and concentrate feed production is needed for more animal food production. 
In order to obtain high efficiency from animals, it is necessary to meet the nutrient needs in a balanced and sufficient level, and for this purpose, it is necessary to use quality roughage and concentrate feed sources. Roughage is generally divided into two groups as dry and watery roughage. Dry roughage, hay, straw and products with a crude cellulose content of $18 \%$ or higher, roughage consists of green fodder plants such as alfalfa, sainfoin, vetch, silage, roots and tubers.

One of the main problems of animal husbandry is the difficulties in obtaining good quality, cheap and sufficient amount of roughage. Many countries are faced with important problems, especially in terms of meeting the need for quality roughage (Kutlu, 2016). Problems in the supply of quality roughage is one of the most important reasons for the low yield per animal in many countries. It is only possible to reduce the amount of intensive feed used in animal feeding, which is expensive, by using quality roughage. In this context, one of the important sources to refer to is silage (Alçiçek, 1995).

It is not possible to meet the nutritional requirements of ruminant animals only with concentrate feeds. It is possible to realize both economical and rational feeding by adding silage as well as concentrate and roughage to the rations. It is possible to meet the green feed requirements of animals fresh from nature only in certain periods of the year due to vegetation conditions. In countries located in the Mediterranean climate zone, the vegetation period is approximately 200 days. Therefore, the fresh and green roughage needs of animals have to be met from different sources during the rest of the year. Green and fresh roughage given to animals by grazing or mowing during vegetation periods cannot be stored for a long time without spoiling due to the high water content they contain. For this reason, water-rich roughage should be stored until the period of use with different methods.

Among the forage crops produced for silage, cereals such as corn, wheat and sorghum, which have high water-soluble carbohydrate content and low buffer capacity, come first, but in many countries, corn silage constitutes a very large part of the total silage production (Yaylak and Alçiçek, 2003). However, sunflower, which is an annual industrial plant in some regions, is thought to be one of the plants that can be an alternative to corn in silage production. Although sunflower is mostly cultivated as a second crop after grains, it is currently used as a source of roughage by ensiling or grazing. Although sunflower is grown for different purposes (oil, pulp and snack food, etc.) around the world, it is also grown as a silage plant in many countries. Sunflower cultivation is easier than corn, and it can be used for silage as an alternative to corn, especially in regions that do not receive much precipitation and irrigation facilities are limited. 
It is possible to benefit from sunflower as an important forage plant, thanks to its ability to be silage in a shorter time than corn, its tolerance to high and low temperatures, and its high adaptability to various soil conditions (Y1ld1z, 2017).

Although silage is one of the most important roughage sources used in the feeding of sheep and goats as well as cattle in countries with developed livestock, silage production and use are still insufficient in some countries. Especially, the use of silage is very low in small ruminant. However, it has been reported that silage feed has started to be used in the rations of small ruminant in recent years (Öztürk, 2000).

In this study, it was aimed to investigate the effects of different silage type, silage consumption, birth type (single or twin) and birth weight on the live weight of Kivirc1k lambs at the end of fattening by using some data mining methods.

\section{Material and Method}

\section{Material}

This study was carried out in a semi-open barn in a sheep farm belonging to Bursa Uludağ University Agricultural Application and Research Center. In the study, 40 Kıvircik male lambs aged 2.5-3 months and an average live weight of 23-25 kg were used as animal material. The fattening lambs were housed in individual compartments during the experiment and individual feeding was applied to the animals during the 56-day fattening period. During the trial period, the live weights and feed consumptions of the lambs were determined individually and in 2week periods.

During the experiment, lambs were fed 5 different silages (100\% sunflower silage, 75\% sunflower $+25 \%$ corn silage, $50 \%$ sunflower $+50 \%$ corn silage, $25 \%$ sunflower $+75 \%$ corn silage, $100 \%$ corn silage) as pure and mixed. Lambs housed in individual chambers consumed the silage mixtures of their groups ad libitum. In addition to the silage mixtures consumed by the lambs, $700 \mathrm{~g}$ of concentrate feed per animal was given in the first 4 weeks of the experiment. Later, this amount was increased to $900 \mathrm{~g}$ for 4 weeks, and to $1400 \mathrm{~g}$ in the last 2 weeks of the experiment, taking into account the daily nutrient needs of the lambs.

The lambs were fed once a day at 09:00 in the morning. The remaining feed from the feeders in the individual compartments was collected and weighed daily before new feeding was made the next day, and the amount of silage mixture and concentrated feed consumed by each animal daily was determined. Fresh and clean drinking water was always available in front of the lambs. During the fattening period, the live weights of the lambs were determined by control 
weighing made every 14 days. Weights of the animals at the beginning of fattening and other control weights were made on an empty stomach.

\section{Method}

Data on fattening results were analyzed with MARS and Bagging MARS algorithms. MARS (Multivariate Adaptive Regression Splines) algorithm, was proposed by Friedman (1991) in order to study the non-linear relationships between input variables and output variable(s). For the MARS algorithm, no assumptions about functional relationships between dependent and input variables are needful. It is a nonparametric statistical method that takes a basis for a divide. The MARS model is highly flexible with the combination of hinge functions and two of them multiplied together, allowing for bends, thresholds, and other departures from typical linear functions (Goh et al. 2016; Zhang et al. 2019)

The optimization procedure of the MARS model primarily consists of forward and backward phases. During this process, the forward phase generates basis functions, and finds the location of potential knots in a stepwise manner, leading to overfitting and complexity. Thereby, the backward phase intends to increase the generalization ability of the model by calculation. Piecewise functions are divided into three: These are a constant, a hinge function and a product of two or more hinge functions for different predictors. A hinge function is as follows (Friedman, 1991).

$$
\max (0, x-t)=\left\{\begin{aligned}
x-t, & x \geq t \\
0, & x<t
\end{aligned}\right.
$$

here $\mathrm{t}$ is the predefined parameter. MARS model is established as a linear combination of basis functions and interrelation, explained as follow (Friedman, 1991).

$$
f(x)=\beta_{0}+\sum_{i=1}^{N} \beta_{i} B_{i}(x)
$$

here each $B_{i}(x)$ is the $\mathrm{i}^{\text {th }}$ basis function. The coefficient $\beta_{0}$ is a constant, while $\beta_{i}$ is the coefficient of the $\mathrm{i}^{\text {th }}$ basis function, determined by the least-squares method, and $\mathrm{f}(\mathrm{x})$ produces the predicted value. The basis function, which demonstrates the largest decline in the training error, will be added to the model up to the specified maximum number of basis functions are achieved. 
Model subsets are compared using generalized cross-validation (GCV). The GCV is a shape of regularization that trades off the goodnessof-fit against the model complexity. The GCV of a model is defined as follows (Hastie et al. 2009):

$$
G C V=\frac{\frac{1}{n} \sum_{i=1}^{n}\left(y_{i}-f\left(x_{i}\right)^{2}\right.}{\left[1 \frac{M+d(M-1) / 2}{n}\right]^{2}}
$$

here $M$ is the number of basis functions, and $d$ is the penalizing parameter. The optimal value of $d$ usually falls in the range of $2 \leq d \leq 4$, and generally $d=3$ is used (Friedman, 1991).

The residuals are the difference between the values $(x)$ predicted by the model and corresponding response values $y$. The residual sum of squares (RSS) is the sum of the squared values of residuals:

$$
R S S=\sum_{i=1}^{n}\left(y_{i}-f\left(x_{i}\right)^{2}\right.
$$

The total sum of squares (TSS) is calculated as the sum over all squared differences between the response $y$ and its mean $\bar{y}$ :

$$
T S S=\sum_{i=1}^{n}\left(y_{i}-\bar{y}\right)^{2}
$$

Generalized $\mathrm{R}^{2}$ or GRSq is the generalization performance of the model estimated using the MARS algorithm. GRSq can be explained as follows (Milborrow, 2021):

$$
G R S_{q}=1-\frac{G C V}{R S S}
$$

GCV is important a statistics for MARS algorithm because it is used to evaluate model subsets in the backward pass.

Bagging (Bootstrap aggregating) MARS algorithm uses bootstrapping among resampling techniques. Bagging models can ensure their own internal estimate of predictive accuracy correlating well with either cross-validation estimates or test set estimates (Kunn and Johnson, 2013). Bagging method is used as a tool to shape a more stable classifier. Bagging predictor is a method to generate multiple versions of predictors and use them for aggregate predictors (Breiman, 1994). Bagging is used for the purpose of improve the classification accuracy of the 
173 MARS method. Thus, this study is expected to obtain better modelling and classification 174 functions through bagging MARS method (Hasyim et al. 2018).

175 To comparatively test the estimate criteria of all the models, the following goodness of fit 176 criteria were determined (Willmott and Matsuura, 2005; Liddle, 2007; Takma et al., 2012; 177 Eyduran et al. 2019):

1. Pearson correlation coefficient (r) between the observed and predicted dependent variable values,

2. Coefficient of Determination

$R^{2}=1-\frac{\sum_{i=1}^{n}\left(y_{i}-\hat{y}_{i}\right)^{2}}{\sum_{i=1}^{n}\left(y_{i}-\bar{y}\right)^{2}}$

3. Adjusted Coefficient of Determination

$\operatorname{Adj} . R^{2}=1-\frac{\frac{1}{n-k-1} \sum_{i=1}^{n}\left(y_{i}-\hat{y}_{i}\right)^{2}}{\frac{1}{n-1} \sum_{i=1}^{n}\left(y_{i}-\bar{y}\right)^{2}}$

4. Root-mean-square error (RMSE) given by the following formula:

$$
R M S E=\sqrt{\frac{1}{n} \sum_{i=1}^{n}\left(y_{i}-\hat{y}_{i}\right)^{2}}
$$

5. Standard deviation ratio $\left(\mathrm{SD}_{\text {ratio }}\right)$ :

$S D_{\text {ratio }}=\sqrt{\frac{\frac{1}{n-1} \sum_{i=1}^{n}\left(\varepsilon_{i}-\bar{\varepsilon}\right)^{2}}{\frac{1}{n-1} \sum_{i=1}^{n}\left(y_{i}-\bar{y}\right)^{2}}}$

6. Mean absolute percentage error (MAPE):

$M A P E=\frac{1}{n} \sum_{i=1}^{n}\left|\frac{y_{i}-\hat{y}}{y_{i}}\right| \cdot 100$

7. Mean absolute deviation (MAD):

$M A D=\frac{1}{n} \sum_{i=1}^{n}\left|y_{i}-\hat{y}\right|$

8. Akaike Information Criteria (AIC):

$$
A I C=n \ln \left[\sum_{i=1}^{n} \frac{\left(y_{i}-\hat{y}_{i}\right)^{2}}{n}\right]+2 k
$$

If its standard ratio value is 0.40 or 0.10 , then a regression model applied had a good fit or a very good fit was underlined that by Grzesiak and Zaborski (2012).

\section{Results and Discussion}


Introductory statistics on birth weight, silage consumption and final live weight in Kivircik lambs according to birth type are given in Table 1.

Table 1. Descriptive statistics for birth type.

As seen in Table 1, 13 of the 40 Kivircik lambs were born as singles and 27 of them were twins. The mean birth weight of the lambs was $4.64 \mathrm{~kg}$ in single and $4.03 \mathrm{~kg}$ in twins. While single lambs consumed an average of $917 \mathrm{~g}$ of silage per day, twin lambs consumed $932 \mathrm{~g}$ of silage. The average live weight at the end of fattening is $37.5 \mathrm{~kg}$ in single lambs and $36.6 \mathrm{~kg}$ in twin lambs. The values belonging to single and twin lambs is presented in Figure 1.

Fig. 1 Silage consumption, live weight at birth and live weight at the end of the fattening period by birth type.

In Table 2, introductory statistics for silage consumption, birth weight and post-fattening live weight are presented according to silage type.

Table 2. Descriptive statistics for silage type.

When evaluated according to the type of silage consumed, the highest average birth weight $(4.56 \mathrm{~kg})$ is lambs fed 50\% corn and 50\% sunflower. The highest fattening weight was found to be $37.4 \mathrm{~kg}$ in the first 3 groups (100\% corn, $75 \%$ corn $+25 \%$ sunflower, $50 \%$ corn $+50 \%$ sunflower fed) (Table 2, Figure 2).

Fig. 2 Silage consumption, birth weight and final live weight according to silage type.

Multivariate Adaptive Regression Splines (MARS) and Bagging MARS algorithms, which are data mining methods, were applied in order to examine the effects of factors affecting the end of fattening body weight Kivircik lambs.

Fattening body weight (LW) variable is the dependent variable, while delivery type (BT), silage type (ST), birth weight (BW) and daily average silage consumption (SC) variables are also independent variables. Goodness of fit statistics calculated for MARS and Bagging MARS algorithms are given in Table 3.

Table 3. Predictive performance of MARS and Bagging MARS algorithms. 
Predictive performances of MARS and Bagging MARS were assessed comparatively in predicting LW. Their goodness-of-fit-criteria outcomes are summarized in Table 3. The superiority order in the predictive accuracy of the mentioned algorithms was MARS > Bagging MARS according to the estimated model evaluation criteria. Inasmuch as, greater in the first criteria is better, whereas smaller in the remaining criteria is better. The predictive performance of the MARS algorithm was found better than Bagging MARS. Results of the MARS algorithm for Kivircik lambs are presented in Table 4. The GCV value of the MARS model was 0.0201. For the Kivircik lambs, the observed LW values of the MARS model with the interaction order of 3 displayed much better fit.

Table 4. Results of the MARS algorithm for Kivircik lambs.

The model equation of the MARS algorithm is as follows.

LW $=42.9-33 *$ Typetwin $-2.75 *$ SilageCorn50Sunflo50 $+8.06 *$ SilageCorn75Sunflo25 $-4.5 *$ SilageSunflower $100+33.5 * \max (0,4.1-\mathrm{BW})-26.7 * \max (0, \mathrm{BW}-4.1)-0.0406 * \mathrm{~m}$ $\operatorname{ax}(0$, silage -745$)+0.034 * \max (0$, silage -774$)+0.0647 * \max (0$, silage -838$)-0.0875 * \mathrm{~m}$ $\operatorname{ax}(0$, silage -960$)-0.266 * \max (0,1024-$ silage $)+0.0265 * \max (0$, silage -1024$)-5.89 * \mathrm{~T}$ ypetwin*SilageCorn25Sunflo75 $-1.27 *$ Typetwin * SilageCorn50Sunflo50 $+6.13 *$ Typetwin * BW-0.0204* SilageCorn75Sunflo25* silage $+7 *$ Typetwin* $\max (0, \mathrm{BW}-4.1)$ $+0.0243 *$ Typetwin $* \max (0,1024$ - silage $)-4.38 * \operatorname{SilageCorn} 25 \operatorname{Sunflo} 75 * \max (0,4.1-\mathrm{BW})$ - $34.7 *$ SilageCorn25Sunflo75*max $(0, \mathrm{BW}-4.1)+0.00549 *$ SilageCorn25Sunflo75*max ( $0,1024$ - silage $)+14 *$ SilageCorn50Sunflo50* $\max (0,4.1-\mathrm{BW})+0.000967 *$ SilageCorn5 0 Sunflo50 $* \max (0$, silage -1024$)+42.9 * \operatorname{SilageCorn} 75 \operatorname{Sunflo} 25 * \max (0, \mathrm{BW}-4.1)-0.1$ $37 *$ SilageCorn 75 Sunflo $25 * \max (0$, silage -1024$)-41 *$ SilageSunflower $100 * \max (0,4.1-$ $\mathrm{BW})+0.00515 *$ SilageSunflower100* $\max (0,1024-$ silage $)+0.0598 * \mathrm{BW} * \max (0,1024-\mathrm{s}$ ilage $)+0.0139 * \max (0, \mathrm{BW}-4.1) *$ silage-6.39*Typetwin $*$ SilageCorn 25 Sunflo75 $* \max (0$ , BW - 4.1) + $0.00468 *$ Typetwin * SilageCorn75Sunflo25* $\max (0,1024-$ silage $)+30.1 * \mathrm{~T}$ ypetwin* SilageSunflower100* $\max (0,4.1-\mathrm{BW})+0.049 *$ SilageCorn25Sunflo75* $\max (0$, $\mathrm{BW}-4.1) *$ silage

Among independent variables, the most important and highest positive effects SilageCorn75Sunflo25*max(0, BW - 4.1), $\max (0,4.1 \quad-\quad \mathrm{BW})$ and Typetwin* SilageSunflower100*max(0, 4.1 - BW) explained the variability in LW in the MARS algorithm, successfully. Likewise, highest negative effects SilageSunflower100 * $\max (0,4.1-\mathrm{BW})$, SilageCorn25Sunflo75 and Typetwin defined the variability in LW in the MARS algorithm.

The relative importance of the independent variables is presented in Table 5.

Table 5. Relative importance of model independent variables. 
As seen in Table 5, the greatest importance order was obtained for silage (100\%), BW (96.7\%), SilageSunflower100 (83\%), SilageCorn25Sunflo75 (74.9\%), SilageCorn75Sunflo25 (72\%), Type twin (67.4\%) and SilageCorn50Sunflo50 (67.4\%).

The distribution graphs of observed predicted values of LW was indicated in Figure 3.

Fig. 3 Observed versus predicted values of LW

The prediction equation of the Bagging MARS algorithm as below.

$$
\begin{aligned}
& \mathrm{LW}=(32.87505 \\
& +\quad 17.8484 * \max (0,4-\mathrm{BW}) \\
& +\quad 13.0234 * \max (0, \mathrm{BW}-4) \\
& \text { - } \quad 18.91613 * \max (0, \mathrm{BW}-4.4) \\
& \text { - } 0.008153931 * \max (0,1020.86 \text {-silage }) \\
& +0.005381609 * \max (0, \text { silage- } 1020.86) \\
& +\quad 3.473147 * \text { Typesingle*max }(0, \mathrm{BW}-4) \\
& +2.749936 * \text { SilageCorn25Sunflo75*max }(0, \mathrm{BW}-4) \\
& +21.03818 * \text { SilageCorn50Sunflo50* } \max (0,4-\mathrm{BW}) \\
& +0.01457022 * \text { SilageCorn } 75 \operatorname{Sunflo} 25 * \max (0,1020.86 \text {-silage }) \\
& \text { - } \quad 14.40757 * \text { SilageSunflower } 100 * \max (0,4-\mathrm{BW}) \\
& +50.10852 \\
& \text { - } \quad 3.484945 * \text { SilageCorn50Sunflo50 } \\
& \text { - } 20.27059 * \max (0, \mathrm{BW}-3.6) \\
& +19.93425 * \max (0, \mathrm{BW}-4.2) \\
& \text { - } \quad 17.32094 * \max (0,4.4-\mathrm{BW}) \\
& +8.801585 * \text { SilageCorn50Sunflo50*max }(0,4.4-B W) \\
& \text { - } 2.844158 * \text { SilageSunflower100*max(0, 4.4-BW) } \\
& +0.003617947 * \max (0,4.4-\mathrm{BW}) * \text { silage } \\
& +0.003469904 * \max (0, \mathrm{BW}-4.4) * \text { silage } \\
& +38.08742 \\
& -0.005349635 * \max (0,1024.79 \text {-silage }) \\
& \text { - } 0.01436351 * \text { SilageSunflower } 100 * \max (0,1024.79 \text {-silage }) \\
& ) / 3
\end{aligned}
$$

According to this obtained equation, in the first bootstrap, an increase of $13.02 \mathrm{~kg}$ in lambs with BW $>4,3.47 \mathrm{~kg}$ in singles with $\mathrm{BW} \leq 4,2.75 \mathrm{~kg}$ for $\mathrm{BW}>4$ fed $25 \%$ corn and $75 \%$ sunflower, $21.04 \mathrm{~kg}$ in $\mathrm{BW} \leq 4$ fed $50 \%$ corn and $50 \%$ sunflower is expected. In the second bootstrap, an increase of $19.93 \mathrm{~kg}$ in lambs with $\mathrm{BW}>4.2,8.8 \mathrm{~kg}$ in those fed with $50 \%$ corn and $50 \%$ sunflower $\mathrm{BW} \leq 4.4$ is expected. In the third bootstrap, a small decrease of $0.005 \mathrm{~kg}$ in those with slage $\leq 1024.79$ and in body weight of $0.014 \mathrm{~kg}$ is expected in lambs with slage $\leq 1024.79 \mathrm{~g}$ fed $100 \%$ sunflower is expected. 
The plot between the predicted and observed LW values is showed in Figure 4 for Bagging MARS algorithm.

\section{Fig. 4 Observed and predicted values of LW}

Altın et al., (2005) determined the body weights of Kıvircık and Karya breeds as $34.70 \mathrm{~kg}$ and $29.92 \mathrm{~kg}$, respectively, in their study on live weight. In addition, with the regression analysis, it was determined that the effect of fattening starter live weight on the live weight at the end of the fattening was significant. The body weight values obtained are lower than the findings in this study. In another study, growth curves of Karacabey Merino x Kivircik crossbred lambs were modeled using Gompertz, Logistic and Linear models. It was determined that the Gompertz model gave better results according to the mean square error and coefficient of determination $\left(\mathrm{R}^{2}\right.$ ) criteria (Y1ldız and Soysal, 2009). In the study of Alarslan and Aygün (2019), live weights of 180-day-old K1vircık lambs were found to be $37.67 \mathrm{~kg}$ in singles and 35 $\mathrm{kg}$ in twins. The reported findings are in agreement with the results of this study. In addition, the researchers used the linear regression model to determine the effect of birth weight and daily age on body weight. With regression analysis, they found the effect of birth weight on live weight at $30^{\text {th }}, 60^{\text {th }}, 90^{\text {th }}, 120^{\text {th }}, 150^{\text {th }}$ and $180^{\text {th }}$ days to be significant.

Ekiz et al. (2009) found the body weight of Turkish Merino, Ramlıc, Kivircık, Chios and Imroz lambs as 41.60, 40.40, 41.96, 26.74 and $26.18 \mathrm{~kg}$, respectively, in a study they conducted at Marmara Animal Breeding Research Institute. The reported values differed from the results in this study. In another study, birth weights were investigated in different genotypes and growth periods. Birth weights in German Black Head x Kıvırcık x Kıvırcık, German Black Head x Merino x Kivırc1k and Kıvırcik genotypes were 4.08, 4.32 and $3.85 \mathrm{~kg}$, respectively, while their 75-day live weight was 19.33, 19.38 and $17.58 \mathrm{~kg}$, respectively (Ekiz and Altınel, 2006). Birth weights were close to the results obtained in this study.

Khan et al (2014) estimated body weight from several linear body characteristics (body length, withers height, chest girth, paunch girth, face length, length between ears, length of ears, width and length of tail) collected from Harnai sheep. Authors were investigated the complex relationship between body weight and the measured characteristics by using scores derived from factor and principal component analyses in multiple regression analysis (MLRA) for male and female sheep. Body weight from morphological characteristics was predicted by Regression tree method. $\mathrm{R}^{2}(\%)$, adjusted $\mathrm{R}^{2}(\%)$, and $\mathrm{RMSE}$ values for weight prediction were predicted very high for MLRA (90.6, 90.3, and 4.635 for male sheep, and 92.4, 92.3, and 4.102 
347 for female sheep), while use of factor scores in MLRA (87.8, 87.6, 0.352 for male sheep and $34892.0,91.9$, and 0.284 for female sheep), and principal component scores $(85.9,85.8$, and 0.367

349 for male sheep and 88.8, 88.7, and 0.335 for female sheep) in MLRA completely removed 350 multicollinearity problem.

\section{Conclusion}

352 In the current research, final live weight of Kivircik lambs were evaluated to on the basis of

353 Multivariate Adaptive Regression Splines (MARS) and Bagging MARS algorithms showing 354 perfect performance as a robust algorithm without overfitting problem. MARS algorithm gave 355 better results than Bagging MARS algorithm in modeling body weight in lambs. It is expected 356 that good results can be achieved in data mining applications such as MARS and Bagging 357 MARS algorithms in livestock data.

358

359 Declarations

360 Funding

361 No funding was received for conducting this study.

\section{Conflict of Interest}

363 The authors declare that they have no conflict of interest.

\section{Ethics approval}

365 The manuscript does not contain clinical studies or patient data.

\section{Consent to participate}

367 All the authors approved the final manuscript.

\section{Consent to publication}

369 All the authors consented the final manuscript.

\section{Data availability}

371 All data generated or analysed during this study are included in this published article.

\section{Code availability}

All codes analysed during this study are included in this published article.

\section{References}

Alarslan E., Aygün, T., 2019. Determination of growth and some morphological traits of Kivirckk lambs in Yalova, J. Anim. Prod., 60(1), 39-50, doi:10.29185/ hayuretim.556669.

Alçiçek, A. 1995. Silo yemi; önemi ve kalitesini etkileyen faktörler. E.Ü.Z.F. Tarımsal Uygulama ve Araştırma Merkezi Yayını No. 22, İzmir. 
Altın, T., Karaca, O., Cemal, İ., Yılmaz, M., Yılmaz, O., 2005. Kıvırcık ve Karya kuzularda besi ve karkas özellikleri. Hayvansal Üretim, 46(1), 19-29.

Breiman, L. 1994. Bagging Predictor Technical Report No. 421. Department of Statistics University of California.

Ekiz, B., Altınel, A., 2006. The growth and survival characteristics of lambs produced by commercial crossbreeding Kivircik ewes with $\mathrm{F}_{2}$ rams with the German BlackHeaded Mutton genotype. Turk. J. Vet. Anim. Sci., 30, 507-512

Ekiz, B., Yılmaz, A., Özcan, M., Kaptan, C., Hanoğlu, H., Erdoğan, I., Yalcıntan, H., 2009. Carcass measurements and meat quality of Turkish Merino, Ramlic, Kivircık, Chios and Imroz lambs raised under an intensive production system. Meat Science, 80, 64-70

Eyduran, E., Akın, M., Eyduran, S. P., 2019. Application of multivariate adaptive regression splines in agricultural sciences through R software. Nobel Bilimsel Eserler Sertifika; p. 20779.

Friedman, J. H., 1991. Multivariate Adaptive Regression Splines. Annals of Statistics, 19(1), $1-67$.

Goh, A. T. C., Zhang, W., Zhang, Y., Xiao, Y., Xiang, Y., 2016. Determination of earth pressure balance tunnel-related maximum surface settlement: a multivariate adaptive regression splines approach. Bull. Eng. Geol. Environ. 77, 489-500.

Grzesiak, W., Zaborski, D., 2012. Examples of the use of data mining methods in animal breeding. In: Data mining applications in engineering and medicine (ed. A. Karahoca). InTech, Rijeka, Croatia. pp. 303-324.

Hastie, T., Tibshirani, R., Friedman, J., 2009. The elements of statistical learning: Data mining, inference, and prediction. 2nd ed. Springer, New York, USA.

Hasyim, M., Rahayu, D. S., Muliawati, N. E., Hayuhantika, D., Puspasari, R., Anggreini, D., Hastari, R. C. 2018. Bootstrap Aggregating Multivariate Adaptive Regression Splines (Bagging MARS) to Analyze the Lecturer Research Performance in Private University. IOP Conf. Series: Journal of Physics: Conf. Series 1114:012117. doi:10.1088/1742-6596/1114/1/012117.

Kara, H., Eroğlu, A., 2018. Tam sayılı doğrusal programlama metodu ile entansif hayvancılık işletmesinin kapasite planlaması: Konya (Ereğli) örneği). Çukurova Journal of Agricultural and food Sciences. 33(2), 31-46.

Khan, M. A., Tariq, M. M., Eyduran, E., Tatliyer, A., Rafeeq, M., Abbas, F., Rashid, N., Awan, M. A., Javed, K., 2014. Estimating body weight from several body measurements in Harnai sheep without multicollinearity problem. The Journal of Animal and Plant Sciences, 24(1), 120-126

Kunn, M., Johnson, K., 2013. Applied predictive modeling. NY. https://doi.org/10.1007/978-1-46146849-3.

Kutlu, H.R., 2016. Tüm yönleriyle silaj yapımı. http://www.zootekni.org.tr/upload/File/ SILAJ\%20EI\%20KTABI.pdf. ÇÜ Ziraat Fakültesi, Zootekni Bölümü. Erişim tarihi: 25.02.2016.

Liddle, A.R., 2007. Information criteria for astrophysical model selection. Monthly Notices of the Royal Astronomical Society: Letters 377: L74-L78.

Milborrow, S., 2021. Notes on the earth package. http://www.milbo.org/doc/earthnotes.pdf.

Öztürk, D., 2000. The characteristics of goat farming systems in Kahramanmaraş in the North Eastern Mediterranean region of Turkey. 7. International Conference on Goats. 15-21 May, France, 360-361. 
Takma, C, Atil, H., Aksakal, V., 2012. Comparison of Multiple Linear Regression and Artificial Neural Network Models Goodness of Fit to Lactation Milk Yields. Kafkas Üniversitesi Veteriner Fakültesi Dergisi 18, 941-944.

Willmott, C., Matsuura, K,. 2005. Advantages of the mean absolute error (MAE) over the root mean square error (RMSE) in assessing average model performance, Climate Research 30, 79-82.

Yaylak, E., Alçiçek, A., 2003. Sı̆̆ır besiciliğinde ucuz bir kaba yem kaynağı: Mısır Silajı. Hayvansal Üretim Dergisi 44(2), 29-36.

Yıldız, G., Soysal, M. İ., 2009. Tekirdağ ilinde yetiştirilen Karacabey merinosu x Kıvırcık melezi kuzularda büyüme eğrisinin farklı modellerle belirlenmesi. Tekirdağ Ziraat $\mathrm{T}$ Fakültesi Dergisi, 6(1), 11-19.

Y1ldız, S., 2017. Saanen x K1l keçisi melezi $\left(F_{1}\right)$ keçilerin rasyonlarında mısır silajı yerine ayçiçeği silajının kullanılmasının rumen ve kan parametreleri ile süt verimi ve bileşimine etkisi. YYÜ Fen Bilimleri Enstitüsü, Zootekni ABD, Doktora tezi, Van.

Zhang, Y. Z., Ma, W., Wang, T. L., Cheng, B. Y., Wen, A., 2019. Characteristics of the liquid and vapor migration of coarse-grained soil in an open-system under constanttemperature freezing. Cold Regions Science Technology 165, 102793.

https://doi.org/10.1016/j.coldregions.2019.102793 
Figures

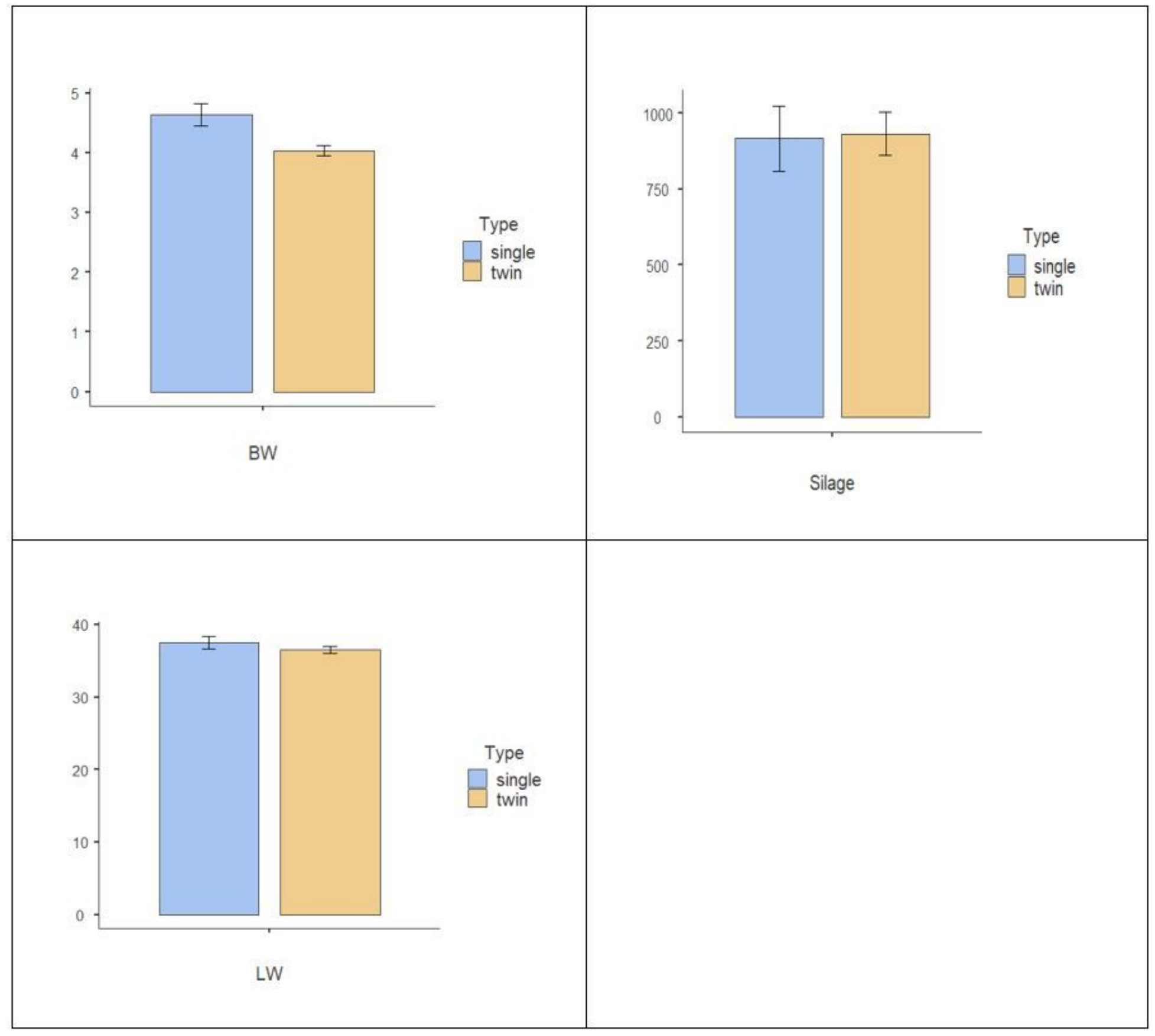

Figure 1

Silage consumption, live weight at birth and live weight at the end of the fattening period by birth type. 




Figure 2

Silage consumption, birth weight and final live weight according to silage type. 


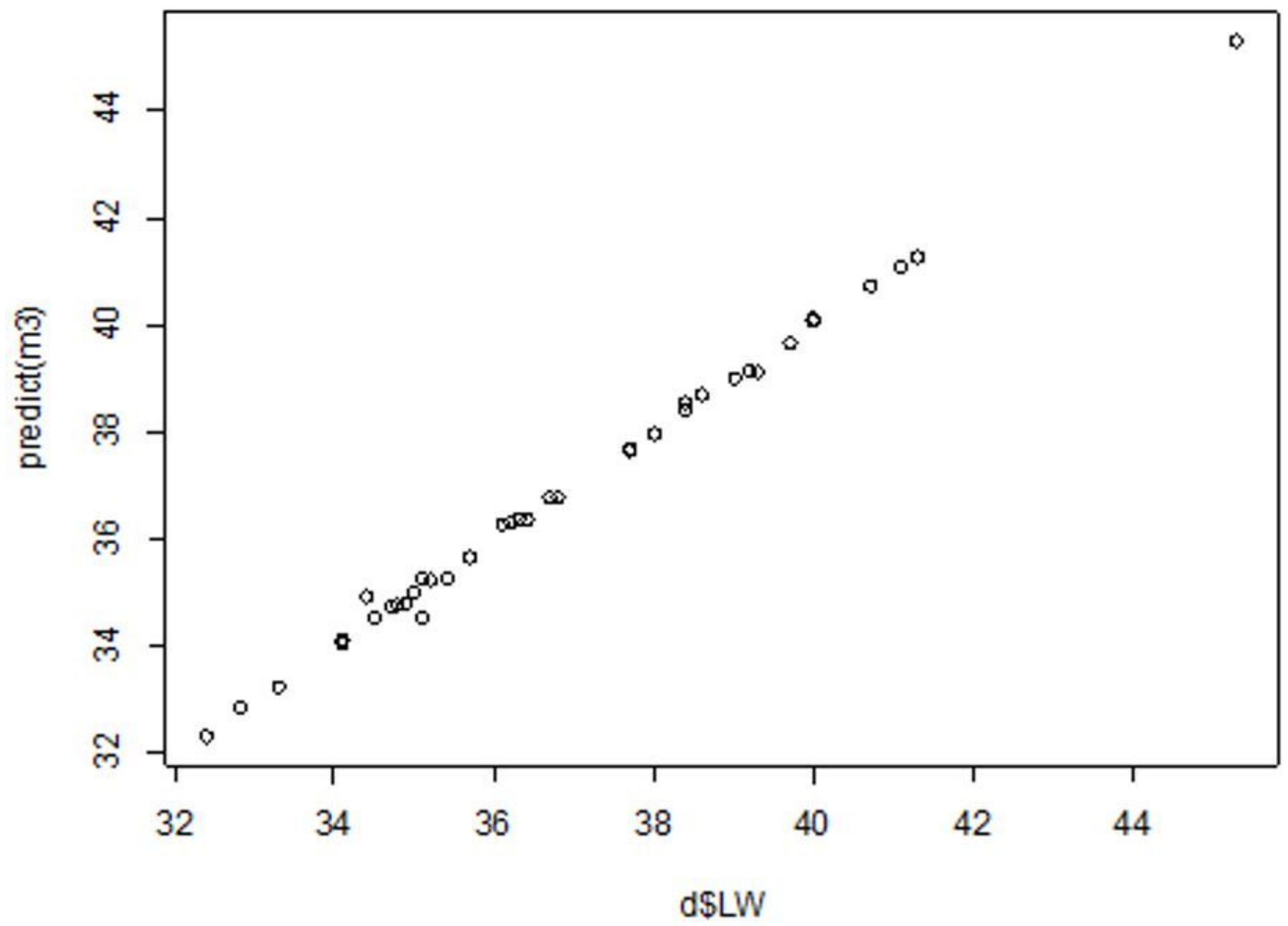

Figure 3

Observed versus predicted values of LW 


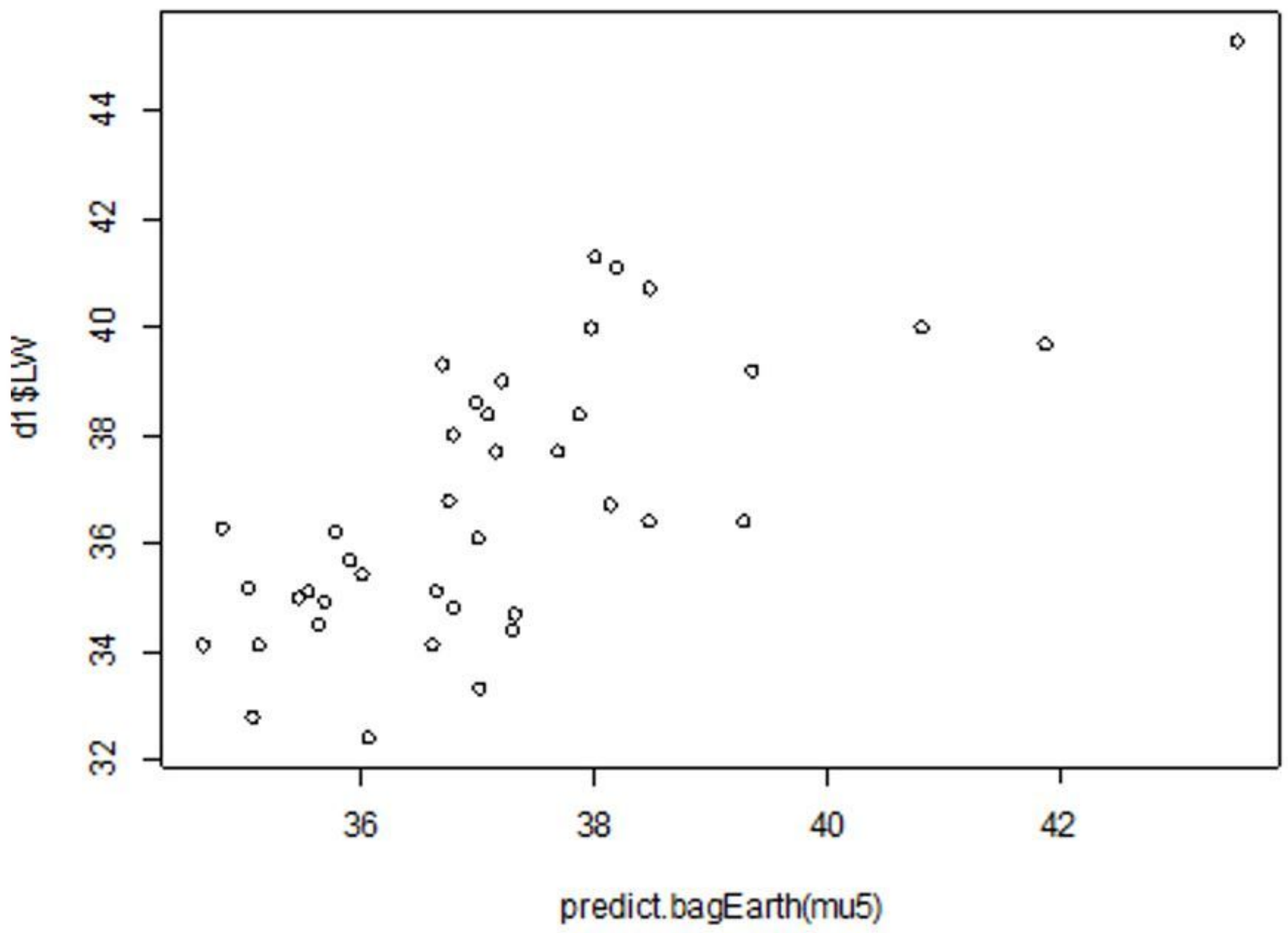

Figure 4

Observed and predicted values of LW 